\title{
The Role of Environmental Learning to Improve Students' Entrepreneurial Intention
}

\author{
Ahmad Jaenudin $^{1}$, Kemal Budi Mulyono ${ }^{2}$, Joko Widodo ${ }^{3}$ \\ \{ahmadjaenudin@mail.unnes.ac.id $\left.{ }^{1}\right\}$ \\ Universitas Negeri Semarang, Indonesia ${ }^{1,2,3}$
}

\begin{abstract}
Entrepreneurship is a positive trend among young people including students. Higher education competes to create graduates who have an entrepreneurial spirit and become young business entrepreneurs. The learning environment is an appropriate instrument of higher education to enhance student entrepreneurship intentions. This study aims to examine the effect of the learning environment through the learning process to increase student entrepreneurial intentions. The design used in this study is the associative design used to analyze the relationships between variables. Collecting data in this study with documentation, observation and questionnaires. Data analysis techniques in this study consisted of (1) descriptive analysis, through the description of the percentage of each variable; (2) as well as statistical analysis through regression tests knowing the relationship between variables. so that it is hoped to be able to explore the findings of a new, more comprehensive and suitable causality path that can be used for proper interpretation of data. The results of this study indicate that the learning environment seen from the learning process as variant (X) has an influence on student entrepreneurial intentions (Y). This is shown by the enthusiasm of students in participating in learning, managing creativity to make innovative products that vary among students. These findings confirm that the learning environment greatly influences entrepreneurial intentions. Therefore, in addition to creativity in processing the learning process to create a pleasant learning environment, the role of universities in improving students' entrepreneurial competencies and skills is urgently needed. So that it can create graduates who have entrepreneurial intentions and have high competitiveness.
\end{abstract}

Keywords: Improve Students', Entrepreneurial, Environmental.

\section{Introduction}

The acceleration of economic growth in a country continues to be done to boost sustainable economic development. Pressure on various fields as a tool to contribute to the economic growth of a country. Entrepreneur and entrepreneurship are considered as important growth agents of a country to achieve economic, social, technological and organizational development [1][2][3]. Currently a positive trend is an effort to create new entrepreneurs who are creative and innovative and have high competitiveness. The effort was carried out by introducing entrepreneurship early on in primary and secondary education and higher education. The study of entrepreneurial intentions is a rapidly developing field of research [4]. The introduction of entrepreneurship is very important because entrepreneurship is one of the economic pillars of a country, especially in Indonesia. In addition, the development of 
sustainable entrepreneurship with government programs namely the National Entrepreneurship Movement [5].

The introduction of entrepreneurship is done through entrepreneurship learning. The important role of entrepreneurship in helping to achieve economic development, competitiveness, job creation and national prosperity has led to real global interest in the development of business and entrepreneurship education, with the hope that this will lead to increased social, economic and organizational development [6]. In this regard, various previous studies mention that entrepreneurial learning has the potential to create one's intention to become an entrepreneur [7]. Entrepreneurial intention is defined as the state of mind of individuals who wish to have a business that leads to the development and application of new business concepts [8][9][10][11].

Efforts to equip students to have entrepreneurial intentions are so that students have additional skills and competencies in addition to academic abilities in higher education. In addition, as an effort to prepare graduates who are qualified and have perceptions of becoming entrepreneurs [12], namely by increasing entrepreneurial intentions that are sustainable. Thus, the orientation or perspective of students after graduating from college is not waiting or looking for work but how they can create jobs through the world of entrepreneurship. At the level of higher education, the effort made is to make the graduates have an entrepreneurial intention through the learning environment in this case the learning process. This can be done is through entrepreneurship lectures that have become compulsory subjects in tertiary education. Through these lectures' students can be given stimulus and motivation in order to have entrepreneurial intentions. So, we need strategies and methods that are creative and innovative in compiling the learning process.

Currently learning is designed to suit the needs of students and the progress of the times. Various platforms of learning media are growing so that students are now freer to choose the media or learning resources they want. Adjustment of the learning process aims to create a conducive learning environment so that learning objectives are achieved well. In general, definitions of the learning environment cover educational approaches, physical arrangements and the cultural context in which learning takes place [13]. Likewise Che Ahmad [14] says a peaceful and comfortable school atmosphere is very important for students and teachers to ensure effective teaching and learning. The learning process really determines the student's output based on his learning experience.

On the other hand, various disciplines combine learning strategies by utilizing conventional learning and digital technology known as blended learning, Roberts [15] mentioning that blended learning strategies have been successfully used in various disciplines of science. This is done so that students have a varied way of learning, namely through faceto-face learning and online learning. With these developments variations in learning and teaching become more creative and innovative. In an effort to improve quality education, the integration of adaptive technology and learning skills has shifted to online learning as trends and models in providing access to resources and information and collaborative learning with unlimited space [16][17][18]. Learning based on internet platforms is known as online learning as a form of educational development [19]. This change is certainly based on the development of science in the field of science and technology.

Changes in the model of education from conventional/traditional to online-based affect every aspect of educational practice meaning that education can be done without going through face-to-face [20][21][22]. This happens in developed countries where the activities of students using digital technology and the internet in everyday life [23][24]. No exception to changes in the learning process that has changed since the modern or digital era changing the 
education system globally [25]. The purpose of education is not only to teach textbooks and make students understand learning materials but also to add creative thinking, creative environments and independence [26]. Along with the advancement of digital learning media developed, the creativity of a teacher or lecturer in managing learning also influences changes in students' behaviour and learning environment. So, it is necessary to increase the competence of an educator to adjust to the needs of current students. Thus, educators must master technology or in other words follow technological developments and changing times, because teachers have become contractors as a determinant of the quality of education [27].

Based on the description above, an understanding can be taken that to instill or increase entrepreneurial intentions can be through the learning environment at tertiary institutions. The effort made is to design a good learning process in entrepreneurship lectures. The learning process is planned by adjusting the needs of students in technological development and advancement of the times. In other words, providing innovation in learning both face to face and with online learning so that learning objectives are achieved. To find out the truth of the above-mentioned research conducted with a hypothesis whether there is an influence of the learning environment on student entrepreneurship intentions.

H1: Is there an influence of the learning environment on student entrepreneurship intentions.

\section{Research Methods}

This research is a type of quantitative research that aims to test the hypotheses that have been set using statistical data analysis. The design used in this study is the associative design used to analyse the relationships between variables. This research was conducted to strengthen the assumption that the learning environment influences the formation of student entrepreneurial intentions. This study answers the question of the importance of entrepreneurial intentions among students who aim to prepare graduates to have the skills and skills in entrepreneurship. The data collection in this study with documentation, observation and questionnaire The steps in this study are (1) observing the research problem, (2) conducting an in-depth literature study, (3) collecting field data, (4) analyzing with numeric data or qualitative data that is framed (scoring) on the research variables, (5) interpreting and discussing the results of the analysis, (5) providing conclusions and suggestions. This research was conducted at Universitas Negeri Semarang involving students who have received entrepreneurship courses.

The research design used by the writer is associative design. Associative design is useful for analyzing the relationship between one variable with another variable or how a variable affects other variables. With this research a theory can be built that can serve to explain, predict, and control a phenomenon. The data obtained in this study will be processed, analyzed, and further processed with statistical testing, namely a regression test to determine the relationship between variables and assisted using SPSS 23 applications. Hypothesis testing is known by comparing the Sig. 0.05 and $t_{\text {count }}$ with $t_{\text {table }}$ so that the research hypothesis will be known. 


\section{Result and Discussion}

\subsection{Result}

This study aims to determine the effect of the relationship of the learning environment on entrepreneurial intentions. The object of this research is students who have taken or are currently studying entrepreneurship at the Faculty of Economics, Semarang State University. Data is collected by giving questionnaires to students related to the learning environment and entrepreneurial intentions. Furthermore, testing is done using a simple regression test to determine whether there is an influence on each variable. The criteria used in drawing conclusions refer to the level of $\alpha=0.05$. H0 is rejected if the significance of the probability ( sig) $<\alpha(0.05)$ or $\mathrm{t}_{\text {count }}>\mathrm{t}_{\text {table }}$ which means there is an influence between the two variables and if the significance level of the probability ( $\mathrm{sig})>\alpha(0.05)$ or $\mathrm{t}_{\text {count }}<\mathrm{t}_{\text {table }}$ then $\mathrm{H} 0$ is accepted which means there is no influence between the two variables. Based on a simple regression statistical test it can be seen the following test results.

Table 1. Output ANOVA

\begin{tabular}{llccccc}
\hline \multicolumn{7}{c}{ ANOVA $^{\mathbf{a}}$} \\
\hline & Model & Sum of Squares & df & Mean Square & F & Sig. \\
\hline 1 & Regression & 71.920 & 1 & 71.920 & 8.093 & $.006^{\text {b }}$ \\
& Residual & 648.747 & 73 & 8.887 & & \\
Total & 720.667 & 74 & & & \\
a. Dependent Variable: IB & & & & \\
b. Predictors: (Constant), LB & \multicolumn{7}{c}{ Source: Data Processing in 2020. }
\end{tabular}

Source: Data Processing in 2020.

Based on Table 1. above, it is known that the F value of 8093 with a significance value of 0.006. Thus, it was concluded that the coefficient of the significant regression equation was seen from the significance value $>0.05$.

Table 2. Model Summary

\begin{tabular}{lcccc}
\hline \multicolumn{5}{c}{ Model Summary } \\
\hline Model & $\mathrm{R}$ & R Square & Adjusted R Square & $\begin{array}{c}\text { Std. Error of the } \\
\text { Estimate }\end{array}$ \\
\hline 1 & $.316^{\mathrm{a}}$ & .100 & .087 & 2.981 \\
a. Predictors: (Constant), LB & & & \\
\hline
\end{tabular}

Source: Data Processing in 2020.

Table 2 explains that the value of the correlation coefficient (model summary) value (R) $=0.316$, this shows there is a relationship between the learning environment $(\mathrm{X})$ and entrepreneurial intentions $(\mathrm{Y})$. The coefficient of determination $(\mathrm{R} 2)=0.100$, this shows that the effect of all independent variables on the dependent variable is $10 \%$ while the remaining 0.90 or $90 \%$ is influenced by other variables other than those examined.

Based on table 3. it can be seen that the significance value of the regression test is 0.005 . The significance value is smaller than 0.05 and the $t_{\text {value }} 2.906>t_{\text {table }} 1.993$ which means that in accordance with the test criteria explain that $\mathrm{H} 0$ is rejected. This shows that there is an influence between the learning environment on entrepreneurial intentions. These results 
indicate that the learning environment influences the intentions of student entrepreneurship, especially in entrepreneurship courses. Based on this, a good learning environment will have an impact on learning objectives and learning outcomes. To need to create a conducive learning environment that includes class learning processes, teaching strategies, mastery of materials and entrepreneurial practices.

Table 3. Output Coefficients

\begin{tabular}{|c|c|c|c|c|c|c|}
\hline \multicolumn{7}{|c|}{ Coefficients $^{\mathrm{a}}$} \\
\hline & \multirow[t]{2}{*}{ Model } & \multicolumn{2}{|c|}{$\begin{array}{l}\text { Unstandardized } \\
\text { Coefficients }\end{array}$} & \multirow{2}{*}{$\begin{array}{c}\text { Standardized } \\
\text { Coefficients } \\
\text { Beta } \\
\end{array}$} & \multirow[t]{2}{*}{$\mathrm{t}$} & \multirow[t]{2}{*}{ Sig. } \\
\hline & & $\mathrm{B}$ & Std. Error & & & \\
\hline \multirow[t]{2}{*}{$\overline{1}$} & (Constant) & 24.153 & 4.188 & & 5.767 & .000 \\
\hline & LB & .313 & .108 & .324 & 2.906 & .005 \\
\hline \multicolumn{7}{|c|}{ a. Dependent Variable: IB } \\
\hline
\end{tabular}

Source: Data Processing in 2020.

\subsection{Discussion}

Based on the test results above, it is known that the learning environment influences student entrepreneurship intentions. These results indicate that the role of the learning environment is very influential for student learning outcomes. The learning environment is one source of learning that affects student learning outcomes and in the learning process [28]. The development of learning is currently supported by technology as an effort to create an innovative and interactive learning environment so that learning resources can be easily obtained in accordance with the basis needed for teaching and learning [29][30]. This is in line with research conducted by Bognár et al. [31] which states that modern learning methods have changed the learning environment at tertiary institutions by increasing the success of learning outcomes. But what needs to be stressed is the effort to create and maintain a conducive learning environment that is sustainable. The learning environment has a big influence on learning success. In this study the learning environment has an influence on student entrepreneurship intentions. The intention of entrepreneurship is said to be the desire or unanimity of an individual to become an entrepreneur. In other words, entrepreneurial intentions are defined as the intention that individuals have to start their own businesses and are the main predictors of future entrepreneurs [11].

This study examines the variables of entrepreneurial intentions as an effort to develop knowledge and train student skills in the learning process, and provide stimulus and direct entrepreneurial practice supported by a learning environment [32]. In addition, the need for an experiential learning approach is available for all students by following a systematic review of the effects of entrepreneurship education [33]. In line with the opinion of Shagrir [34] that during the learning process the teacher supports students to prepare learning tools and systems according to their needs and is directed to increase greater entrepreneurial intentions. Furthermore Barba-Sánchez \& Atienza-Sahuquillo [35] that entrepreneurial learning has a positive contribution in triggering student entrepreneurial intentions that are supported by a pattern of independent entrepreneurial activities. Furthermore aspects of entrepreneurial intentions depend on the extent to which students can utilize their personal abilities to develop effective learning processes [36].

Entrepreneurship learning that is supported by a good learning environment will provide a good stimulus to entrepreneurial intentions. This is supported by research conducted by 
Moraes [37] which states there is a positive relationship between the context of entrepreneurship education and entrepreneurial intentions that are strengthened with entrepreneurial studies and evaluation of student entrepreneurial characteristics in the learning process. The stronger the entrepreneurial intentions of each individual, the more likely it is to become an entrepreneur [38]. In line with the above opinion, research Teixeira et al. [10] which states the main determinant of entrepreneurial intentions is the capacity felt by individuals, entrepreneurial intentions themselves which in fact will affect the birth of new entrepreneurs, financing for entrepreneurs, basic education and training as well as the influence of research and development. The main problem that must be solved is the design of an adequate learning process to motivate students to become entrepreneurs [39]. Thus, efforts to instill students' entrepreneurial intentions through the learning environment will be easily implemented.

The high trend of entrepreneurship provides a new culture for educational institutions to compete in creating new entrepreneurs. As with research conducted by Sparkes et al. [40] where the demand for new entrepreneurs requires universities to develop through the creation of an entrepreneurial education platform whose contents are the entrepreneurial team, the provision of mentors, the provision of friends and learning resources, and creating social networks. This shows that the role of universities is very large in creating new entrepreneurs. In addition, the most important effort to develop student entrepreneurial intentions is the role of education and entrepreneurship in higher education cannot be separated. The identification and analysis is carried out through the development center and programs on entrepreneurship education [41]. Therefore, universities must fully support study programs and entrepreneurship courses into compulsory lectures so that students can be motivated to have entrepreneurial intentions and have high competitiveness after they graduate from college.

Besides going through the learning environment or the learning process of higher education, it can also provide entrepreneurship education and training. In accordance with research conducted by Gieure et al. [42] states students are more likely to acquire entrepreneurial skills through effective education and training. Entrepreneurial skills play an important role in explaining entrepreneurial intentions because it is assumed that knowledge and training make people very skilled. This raises the tendency for people to start a business. For the continued fulfillment of new entrepreneurs there must be research and development efforts as a reference to provide innovation in the sustainability of the entrepreneurship field. Future entrepreneurial research must focus on social cognitive categories (people, context, cognition and motivation). In recent years, concerns about understanding key elements involved in the entrepreneurial process have increased [4], much research focusing on entrepreneurial cognition as a knowledge structure that people use to make judgments, judgments or decisions involving evaluation opportunity, business creation and growth.

\section{Conclusion}

This study aims to determine the effect of the learning environment on student entrepreneurial intentions. Based on the results of the analysis and discussion it is known that the learning environment has an influence on student entrepreneurial intentions. This is evidenced by the statistical analysis of the regression test as the applicable provisions show a significance value that is, $0.005<0.05$ and $t_{\text {count }}$ value $2.906>1.993 \mathrm{t}_{\text {table, }}$, which means the learning environment variable $(\mathrm{X})$ has an influence on the entrepreneurial intention variable 
(Y). The various factors that influence learning environment variables one of which is the process of learning and entrepreneurship courses. An interesting and enjoyable learning process becomes the main trigger for students to follow entrepreneurship learning well. In addition, learning with a student-centered learning approach is by involving students directly in learning. Furthermore, in learning students are given the opportunity to become an entrepreneur starting from making plans, making products, marketing, and competing with other students and evaluating their activities. This is what motivates students to take part in learning and have high entrepreneurial intentions

The role of universities as a forum to create graduates who have an entrepreneurial spirit and become a young entrepreneur is very important. Efforts are being made to provide full support to study programs to provide the best service in the entrepreneurial learning process. The expected output is students have entrepreneurial skills and competencies and have high competitiveness. In addition, tertiary education graduates are not endlessly waiting for a job call or as a job seeker but are able to become an entrepreneur independently and open up a job creator. Thus, a learning environment that includes a good learning process will influence student entrepreneurship intentions with the support of universities to create the best graduates.

\section{References}

[1] L. Ács, Z. J., Autio, E., \& Szerb, "National Systems of Entrepreneurship: Measurement issues and policy implications," Res. Policy, vol. 43, no. 3, pp. 476-494, 2014.

[2] E. Bosma, N., Content, J., Sanders, M., \& Stam, "Institutions, entrepreneurship, and economic growth in Europe," Small Bus. Econ., vol. 51, no. 2, pp. 483-499, 2018.

[3] R. K. Sahoo, S., \& Panda, "Exploring entrepreneurial orientation and intentions among technical university students: Role of contextual antecedents," Educ. Train., vol. 61, no. 6, pp. 718-736, 2019.

[4] M. Liñán, F., Urbano, D., \& Guerrero, "Regional variations in entrepreneurial cognitions: Startup intentions of university students in Spain," Entrep. Reg. Dev., vol. 23, no. 3-4, pp. 187-215, 2011.

[5] N. Trisnawati, "Pengaruh Pengetahuan Kewirausahaan Dan Dukungan Sosial Keluarga Pada Minat Berwirausaha Siswa Smk Negeri 1 Pamekasan," J. Ekon. Pendidik. Dan Kewirausahaan, vol. 2, no. 1, p. 57, 2017.

[6] R. Bell, "Predicting entrepreneurial intention across the university," Educ. Train., vol. 16, no. 7-8, pp. 815-831, 2019.

[7] A. Ghina, A., Simatupang, T. M., \& Gustomo, "The relevancy of graduates' competencies to the effectiveness of entrepreneurship education: A case study at SBM ITB-Indonesia," $J$. Entrep. Educ., vol. 20, no. 1, pp. 1-24, 2017.

[8] J. O. Bae, T. J., Qian, S., Miao, C., \& Fiet, "The Relationship Between Entrepreneurship Education and Entrepreneurial Intentions: A Meta-Analytic Review," Entrep. Theory Pract., vol. 38, no. 2, pp. 217-254, 2014.

[9] L. Sharma, "Entrepreneurial intentions and perceived barriers to entrepreneurship among youth in Uttarakhand state of India: A cross-cultural investigation across genders," Int. J. Gend. Entrep., vol. 10, no. 2, pp. 243-269, 2018.

[10] M. D. Teixeira, S. J., Casteleiro, C. M. L., Rodrigues, R. G., \& Guerra, "Entrepreneurial intentions and entrepreneurship in European countries," Int. J. Innov. Sci., vol. 10, no. 1, pp. $22-42,2018$.

[11] O. B. Yıldırım, N., Çakır, Ö., \& Aşkun, "Ready to Dare? A Case Study on the Entrepreneurial Intentions of Business and Engineering Students in Turkey," Procedia - Soc. Behav. Sci., vol. 
229, pp. 277-288, 2016.

[12] K. Vuorio, A. M., Puumalainen, K., \& Fellnhofer, "Drivers of entrepreneurial intentions in sustainable entrepreneurship," Int. J. Entrep. Behav. Res., vol. 24, no. 2, pp. 359-381, 2018.

[13] D. Apostolopoulos, N., Kakouris, A., Liargovas, P., Dermatis, Z., \& Komninos, "Evaluating the learning environment of a cross-institutional postgraduate programme in entrepreneurship," Entrep. Educ., vol. 1, no. 1-4, pp. 105-123, 2018.

[14] M. F. N. L. Che Ahmad, C. N., Shaharim, S. A., \& Abdullah, "Teacher-student interactions, learning commitment, learning environment and their relationship with student learning comfort," J. Turkish Sci. Educ., vol. 14, no. 1, pp. 57-72, 2017.

[15] C. Roberts, J. C., Ritsos, P. D., Jackson, J. R., \& Headleand, "The Explanatory Visualization Framework: An Active Learning Framework for Teaching Creative Computing Using Explanatory Visualizations," IEEE Trans. Vis. Comput. Graph., vol. 24, no. 1, pp. 791-801, 2018.

[16] R. Huda, M., Maseleno, A., Teh, K. S. M., Don, A. G., Basiron, B., Jasmi, K. A., Mustari, M. I., Nasir, B. M., \& Ahmad, "Understanding Modern Learning Environment (MLE) in big data era," Int. J. Emerg. Technol. Learn., vol. 13, no. 5, pp. 71-85, 2018.

[17] S. Kang, M., Liew, B. T., Lim, H., Jang, J., \& Lee, "Lecture Notes in Educational Technology Learning Environments,” Emerg. Issues Smart Learn., pp. 209-216, 2015.

[18] V. Mulwa, C., Lawless, S., Sharp, M., Arnedillo-Sanchez, I., \& Wade, "Adaptive educational hypermedia systems in technology enhanced learning: A literature review," SIGITE'10 - Proc. 2010 ACM Conf. Inf. Technol. Educ., pp. 73-84, 2010.

[19] Q. Xin, Y., Zuo, X., \& Huang, "Research on the construction of seamless learning platform based on open education," Asian Assoc. Open Univ. J., vol. 13, no. 1, pp. 88-99, 2018.

[20] S. S. Al-Gahtani, "Empirical investigation of e-learning acceptance and assimilation: A structural equation model," Appl. Comput. Informatics, vol. 12, no. 1, pp. 27-50, 2016.

[21] J. S. Hong, J. C., Tai, K. H., Hwang, M. Y., Kuo, Y. C., \& Chen, "Internet cognitive failure relevant to users' satisfaction with content and interface design to reflect continuance intention to use a government e-learning system," Comput. Human Behav., vol. 66, pp. 353-362, 2017.

[22] D. Luo, N., Zhang, M., \& Qi, "Effects of different interactions on students' sense of community in e-learning environment," Comput. Educ., vol. 115, pp. 153-160, 2017.

[23] J. W. Gallardo-Echenique, E. E., Marqués-Molías, L., Bullen, M., \& Strijbos, "Let's talk about digital learners in the digital era," Int. Rev. Res. Open Distance Learn., vol. 16, no. 3, pp. 156187, 2015.

[24] Y. B. D. Kolikant, "Digital natives, better learners? Students' beliefs about how the Internet influenced their ability to learn," Comput. Human Behav., vol. 26, no. 6, pp. 1384-1391, 2010.

[25] H. Weigel, M., James, C., \& Gardner, "Learning: Peering Backward and Looking Forward in the Digital Era," Int. J. Learn. Media, vol. 1, no. 1, pp. 1-18, 2009.

[26] K. Kalyani, D., \& Rajasekaran, "Innovative Teaching and Learning," J. Appl. Adv. Res., vol. 3, no. 1, p. $23,2018$.

[27] R. D. Retnawati, H., Djidu, H., Kartianom, Apino, E., \& Anazifa, “Teachers' knowledge about higher-order thinking skills and its learning strategy," Probl. Educ. 21st Century, vol. 76, no. 2, pp. 215-230, 2018.

[28] P. Anggraini, Y., Patmanthara, S., \& Purnomo, "Pengaruh lingkungan belajar dan disiplin belajar terhadap hasil belajar kompetensi keahlian elektronika industri di sekolah menengah kejuruan," J. Pendidik. Teor. Penelit. Dan Pengemb., vol. 2, no. 2, pp. 1650-1655, 2017.

[29] L. S. Anshari, M., Alas, Y., \& Guan, "Developing online learning resources: Big data, social networks, and cloud computing to support pervasive knowledge," Educ. Inf. Technol., vol. 21, no. 6, pp. 1663-1677, 2016.

[30] A. B. C. Huda, M., Haron, Z., Ripin, M. N., Hehsan, A., \& Yaacob, "Exploring innovative learning environment (ILE)," Int. J. Appl. Eng. Res., vol. 12, no. 7, pp. 6678-6685, 2017.

[31] B. Bognár, L., Éva, H., Joós, A., \& Nagy, "Improved learning environment for calculus courses," J. Appl. Tech. Educ. Sci., vol. 8, no. 4, 2018.

[32] U. Melati, I. S., Jaenudin, A., \& Widyastuti, "Which is the most appropriate learning model to 
improve students' entrepreneurial interest? A comparison of two kinds of action research," Humanit. Soc. Sci. Rev., vol. 8, no. 2, pp. 58-66, 2020.

[33] A. Nabi, G., Linan, F., Fayolle, A., Krueger, N., \& Walmsley, "The impact of entrepreneurship education in higher education," Acad. Manag. Learn. Educ., vol. 16, no. 2, pp. 277-299, 2017.

[34] L. Shagrir, "Working with students in higher education - professional conceptions of teacher educators," Teach. High. Educ., vol. 20, no. 8, pp. 783-794, 2015.

[35] C. Barba-Sánchez, V., \& Atienza-Sahuquillo, "Entrepreneurial intention among engineering students: The role of entrepreneurship education," Eur. Res. Manag. Bus. Econ., vol. 24, no. 1, pp. 53-61, 2018.

[36] \& R.-F. Córcoles-Muñoz, Parra-Requena, Ruiz-Ortega, García-Villaverde, "Psychological and Biographical Determinants of Entrepreneurial Intention: Does the Learning Environment Act as a Mediator?," Adm. Sci., vol. 9, no. 2, p. 33, 2019.

[37] M. Moraes, G. H. S. M. de, Iizuka, E. S., \& Pedro, "Effects of Entrepreneurial Characteristics and University Environment on Entrepreneurial Intention," Rev. Adm. Contemp., vol. 22, no. 2, pp. 226-248, 2018.

[38] B. Maresch, D., Harms, R., Kailer, N., \& Wimmer-Wurm, "The impact of entrepreneurship education on the entrepreneurial intention of students in science and engineering versus business studies university programs," Technol. Forecast. Soc. Change, vol. 104, pp. 172-179, 2016.

[39] H. Van Auken, "Influence of a culture-based entrepreneurship program on student interest in business ownership," Int. Entrep. Manag. J., vol. 9, no. 2, pp. 261-272, 2013.

[40] M. Sparkes, D., Schmidlin, K., \& Hsu, "Virtual learning environment for entrepreneurship: A conceptual model," IMSCI 2016 - 10th Int. Multi-Conference Soc. Cybern. Informatics, vol. 14, no. 3, pp. 301-303, 2016.

[41] M. D. Barral, M. R. M., Ribeiro, F. G., \& Canever, "Influence of the university environment in the entrepreneurial intention in public and private universities," RAUSP Manag. J., vol. 53, no. 1, pp. 122-133, 2018.

[42] S. Gieure, C., Benavides-Espinosa, M. del M., \& Roig-Dobón, "Entrepreneurial intentions in an international university environment," Int. J. Entrep. Behav. Res., vol. 15, no. 8, pp. 1605-1620, 2019. 